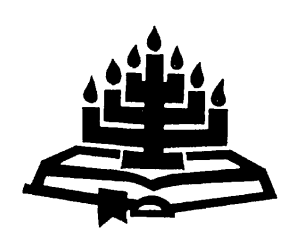

\title{
Die verhouding tussen openbaring, dogmavorming en doksa-uiting in die himniese stof van die Nuwe Testament
}

\author{
J.P. (Johannes) Bingle \& B.J. (Ben) de Klerk \\ Departement Praktiese Teologie \\ Skool vir Kerkwetenskappe \\ Potchefstroomse Universiteit vir $\mathrm{CHO}$ \\ POTCHEFSTROOM \\ E-pos: jpbingle@africaonline.com.na \\ kwsbjdk@puknet.puk.ac.za
}

\begin{abstract}
The relation between revelation, the formation of dogma and the expression of doxa in the hymnal matter of the New Testament

This article proceeds from the central theoretical argument that in the liturgical song an integral relation exists between revelation, the formation of confession (dogma) and the expression of glory (doxa). The purpose of the article is to analyse the mentioned relationship as it becomes manifest in the hymnal matter of the New Testament and to determine its significance in the hymnal action of the community of worshippers. It is kept in mind that the New Testament, unlike the Old Testament, does not contain a book of songs and that the number of complete songs is limited. The article thus also focuses on song fragments. The conclusion arrived at is that the song material of the New Testament indicates that the revelation stands in a causal relation to dogma formation and doxa expression that occur in the liturgical song. Dogma formation and doxa expression respond to the revelation and actualize the revelation, while these two vital elements of the hymnal content (dogma formation and doxa expression) stand in a convergent and symbiotic relation to each other. The result of this investigation appears to be important for the meaningful use of New Testament songs in contemporary liturgy.
\end{abstract}


Opsomming

Die verhouding tussen openbaring, dogmavorming en doksa-uiting in die himniese stof van die Nuwe Testament

In hierdie artikel word uitgegaan van die sentrale teoretiese siening dat daar in die liturgiese lied 'n integrale verhouding tussen openbaring, die vorming van belydenis (dogma) en die uiting van verheerliking (doksa) bestaan. Die doel van die artikel is om die genoemde verhouding soos dit in die himniese stof van die Nuwe Testament aan die lig kom, te ontleed en die betekenis daarvan vir die himniese handeling van die aanbiddingsgemeenskap vas te stel. Dit word in gedagte gehou dat die Nuwe Testament nie soos die $\mathrm{Ou}$ Testament 'n liedbundel bevat nie en dat die aantal volledige liedere beperk is. Die ondersoek fokus daarom ook op liedfragmente. Die konklusie is dat dit vanuit die liedmateriaal van die Nuwe Testament blyk dat die openbaring in 'n kousale verband staan tot die dogmavorming en doksa-uiting wat in die liturgiese lied plaasvind. Die dogmavorming en die doksa-uiting respondeer op die openbaring en aktualiseer die openbaring, terwyl dié twee wesenselemente van die himniese stof (dogmavorming en doksa-uiting) in 'n konvergerende en simbiotiese verhouding tot mekaar staan. Die resultaat van die ondersoek blyk van belang te wees vir die sinvolle gebruik van Nuwe-Testamentiese liedere in die hedendaagse liturgie.

\section{Inleiding}

Die Nuwe Testament, anders as die Ou Testament, bevat nie 'n liedbundel nie en die himniese stof in die Nuwe Testament is nie oral volledige liedere nie. Dit maak 'n himnologiese ondersoek in 'n mate problematies. Die himniese stof is versprei in verskillende boeke van die Nuwe Testament en in baie gevalle is dit wat voorkom, fragmentaries van aard. Die liedere of lieddele lei waarskynlik terug na liedere wat in gebruik was en algemeen bekend was met die formasie van die NuweTestamentiese kerk, maar nie as geïnspireerde openbaring op skrif gestel is nie. Die Bybelskrywer het liturgiese materiaal "geleen" (vgl. Bailey \& Vander Broek, 1992:79) en opgeneem in die konteks van sy "teologiese betoog". Die opneem behels 'n interpretatiewe en selfs vrye omgang met die himne, wat natuurlik die poging om die oorspronklike lied vas te stel, kan bemoeilik. Paulus voeg byvoorbeeld twee glosse by die Christologiese himne in Kolossense 1:15-20 in om te toon hoe die lied in verband met sy verkondiging staan (die "van die kerk" in vers 18 en die verwysing na die kruis in vers 20 is moontlik insetsels van Paulus). Hy is immers nie besig om te sing nie, maar om te onderrig (vgl. Schweizer, 1990:99). Die lied is dus waarskynlik nie verbatim aangehaal nie; wat in die teks weergegee is, verskil op bepaalde punte van die oorspronklike redaksie van die lied. Die werklike lied lê agter die teks. 
Daar is verder byvoorbeeld reeds deur Cryer en Bultmann in 1921 en 1923 die moontlikheid genoem dat 'n Vorlage as onderbou van die Logos-himne van Johannes 1:1-18 onderskei kan word (vgl. Louw, 1989: 39). Moontlik was dit oorspronklik 'n Joodse lied oor die Wysheid wat deur Johannes en dié uit sy kring omgewerk is tot 'n lied op Jesus as die kosmiese logos wat mens geword het. Die omwerking behels onder andere die onderbreking van die poëtiese strukturering deur prosainsetsels (byvoorbeeld vers 6-9, 12-13, 15-17). So kan by elke lied of liedfragment in die Nuwe Testament 'n agtergrondondersoek van die stof gedoen word. Baie moeite word inderdaad deur Nuwe-Testamentici gedoen om by elke lied of liedfragment die sogenaamde oorspronklike lied na te speur.

Dit kan seker aanvaar word dat liedere in die Nuwe Testament se data grootliks onder die oppervlak van die Bybelteks lê (Martin, 1993a:419). Vir die doeleindes van die fokuspunt van dié artikel blyk dit nie nodig te wees om die lied of liedfragment se agterliggende geskiedenis en rekonstruksiemoontlikhede in besonderhede te oorweeg nie. Daar word aansluiting gevind by Botha (1989:57) se benadering: die werking van die himneteks voor hande word in die konteks van die betrokke Bybelboek ondersoek (dus: 'n funksionele verklaringsbenadering, en nie 'n argeologiese benadering nie). Verder word die himniese stof in die ondersoek - naas die fokus op hulle funksie in hulle kanoniese konteks as liturgiese liedere aanvaar.

\section{Basisteoretiese riglyne van liturgies-himnologiese belang en betekenis uit die himniese stof van die Nuwe Testament}

\subsection{Die rol van openbaring in (die vorming van) die liturgiese lied in die Nuwe Testament}

\subsubsection{Die rol van die Ou-Testamentiese openbaring in die himniese stof van die Nuwe Testament}

Dit is opvallend dat die liedere van die Ou Testament dikwels in die Nuwe Testament aangehaal word. Die Ou-Testamentiese liedere kom uit die openbaring en word in die tyd van vervulling weer in die openbaring opgeneem. (Die Psalms word dikwels aangehaal: van die 287 OuTestamentiese aanhalings in die Nuwe Testament kom 116 uit die Psalter - vgl. Williamson, 1976:76). Tog kry dit nou nuwe betekenis in die lig van die voortgaande openbaring. 'n Treffende voorbeeld daarvan is Petrus se aanhaling (uit die Septuagint) van Psalm 16:8-11; onder andere die woorde: "Daarom is my hart bly en my tong jubel" (Hand. 
2:26). Dit is deel van sy Pinkstertoespraak of -preek. Wat nou die "hart blymaak" en die "tong" laat "jubel", is nie net meer die openbaring in konkrete openbaringsdade aan die oorspronklike Psalmdigter nie, maar die groot dade van God in Jesus Christus, soos bevestig in die uitstorting van die Heilige Gees. Die openbaring in die Psalm word sodoende (in sy himniese vorm) deel van die Nuwe Testament se himniese stof. So pas Petrus die aangehaalde Psalm toe. Die lied vloei steeds uit die openbaring voort, maar is nou ook in God se volle openbaring in Christus gegrond, en deur die uitgestorte, vervullende Gees aangevuur (vgl. ook Paulus se verbandlegging tussen die Gees en die lied in Ef. 5:18-19).

Gevolgtrekking: Die Ou-Testamentiese aangehaalde lied in die Nuwe Testament wortel nie net in die Ou-Testamentiese openbaring nie, maar ook in die sensus plenior (voller betekenis) van God se openbaring.

\subsubsection{Openbaring en liedere in die evangelie}

Teen dié agtergrond is dit verder opvallend dat himniese stof in die Nuwe Testament wat nie (soos Psalm 16 en baie ander) direk uit die Ou Testament kom nie, óók wortel in die openbaring - en dikwels juis ook nog in dié van die Ou Testament. Die aangrypende wyse, byvoorbeeld, waarop die Lukas-evangelie met lofsange begin, bevestig dat die lied in die Nuwe Testament steeds deur die openbaringsdade van die verlede gevoed en veroorsaak word. Die Lukaanse himnes, met name dié van Maria (die Magnificat - Luk. 1:46-55), Sagaria (die Benedictus - Luk. 1:68-79) en Simeon (die Nunc Dimittis - Luk. 2:29-32 ), is met hulle kaleidoskoop van Ou-Testamentiese tematiek (vgl. Vorster, 1979:15) goeie voorbeelde hiervan. Dié liedere word deur die meeste kommentatore ook sonder meer as psalms aangedui (vgl. daarvoor Viljoen, 1990: 146). Die liedere moet myns insiens in tweërlei opsig as tussentestamentêre liedere gesien word:

- Temporeel - dié liedere kon in die Joodse apokaliptiek ná die OuTestamentiese tyd ontstaan het, maar is steeds duidelik gevoed deur Jahwe se openbaring in die vroeër tyd.

- Materieel - hierdie liedere sluit die openbaring van die Ou Testament (alhoewel dan nie woordeliks soos Psalm 16 en andere nie) in die Nuwe Testament in.

Op dié wyse het die eerste liedere van die Nuwe Testament - deur Lukas in die mond van Maria, Sagaria en Simeon gelê - 'n skakelfunksie in die openbaring. Strydom (1984:31) stel dit selfs so dat liedere die brug vorm tussen die testamente. Die tema belofte-vervulling is sterk daarin uitgewerk (vgl. Vorster, 1989:29). Die beloftes wat gegrond was/is in die openbaringshandelinge in die ou tyd het nou in die nuwe, vervullende 
openbaring in die koms van die Messias gekonkretiseer. Die gevolg hiervan is dat die lied in die Christelike Kerk voortstu met " $n$ nuwe impetus, gebore uit en as geloofsreaksie op die volledige selfopenbaring van God in Jesus Christus" (Strydom, 1984:23).

Gevolgtrekking: Die openbaring (oud en nuut) veroorsaak die lied in die evangelie, terwyl die lied die ou en nuwe openbaring aaneenskakel. Die lied in die Christelike kerk is 'n geloofsreaksie op die volledige selfopenbaring van God in Jesus Christus.

\subsubsection{Openbaring en liedmateriaal in die Apokalips}

Viljoen (1990:154-159) toon aan dat die talle himnes in die Apokalips aan die einde van die Nuwe Testament ook dié besondere verbindende funksie vertoon. Die liedere lig openbarings en gebeure, in die verlede én die toekoms, toe en skerp hulle in. Maar die belangrike vir die doeleindes van die toetsing van die gestelde basisteoretiese riglyn is om die rol van die openbaring in die lied raak te sien (die volgende riglyn stel die omgekeerde: die rol van die lied in die openbaring; vgl. 2.2). Dit blyk dus dat sowel die liedere aan die begin van die nuwe bedeling (soos weergegee in die evangelie-verhaal) as die liedere wat ' $n$ interpretasie is van die voleinding van die nuwe ryk (in die Apokalips opgeteken), dieselfde funksie vertoon, naamlik aaneenskakeling van openbaring.

Gevolgtrekking: Die liedere in die Apokalips vervul ook 'n skakelfunksie en is niks anders nie as die vrug van dit wat dit aaneenskakel, naamlik die openbaring (waarop dit berus).

\subsubsection{Die (O)openbaring van God en liedere wat tydens die ontvouing van die koninkryk ontstaan}

Tussen die begingebeure en die eindgebeure van die nuwe bedeling wat in die Nuwe Testament se liedere figureer, lê natuurlik die formasie van die Nuwe-Testamentiese kerk. Dit is opvallend hoe ook dít (God se vestiging van Christus se kerk deur sy Woord en Gees) juis die oorsaak en begronding van liedere is. Al kan die werklike Sitz im Leben van die liedere moeilik bepaal word, kan aanvaar word dat dit wat die Bybelskrywers as deel van die formasie en vestiging van die kerk opteken, óók 'n gevolg is van die handelende Christus se werk. Die liedere leef op uit die handelinge van die Beeld/Openbaring van die onsienlike God (Kol. 1:15). Die besondere rol wat die openbaring in die ontstaan van liedere speel, kan waargeneem word deur dit te kontrasteer met die godsdienshistoriese omgewing waarin die koninkryk deurbreek. Hoe lyk die wêreld waarin die koninkryk deurbreek en die kerk vestig? (Dit word hier redelik in besonderhede weergegee, aangesien dit verderaan in die 
artikel weer ter sprake kom.) Martin (1993c:260) se opsomming van die godsdienshistoriese situasie ten tye van die Nuwe-Testamentiese openbaringstyd trek saam in die aanslag van die Gnostisisme op die koninkryk in sy ontvouing. Die belangrikste kenmerke van hierdie leer is volgens hom:

- die ontkenning van Christus as Here en enigste Middelaar tussen God en wêreld;

- 'n verswakte morele lewensuitkyk wat Christene onverskillig maak teenoor sondige begeertes;

- onsekerheid oor die sin van die lewe, omdat die hemelliggame en afgode steeds heers en tevrede gestel moet word.

Dié kenmerke berus almal op een beginsel: God (wat suiwer Gees is) is geskei van die wêreld wat boos is. Die ruimte tussen God en wêreld was gevul met 'n reeks emanasies of aeone, wat van God af gestrek het tot by die wêreld, en wat almal boos was. Wat nodig was, was dus gemeenskap met 'n god wat sy volgelinge kon bevry uit die verknegting aan astrologiese magte. So ' $\mathrm{n}$ god is gehuldig as kurios en soter (vgl. ook Snyman,1989:45-46). 'n Gevoel van onsekerheid, ontreddering en pessimisme het oor die kultuur- en religieuse wêreld gehang. Die mense in dié leefwêreld het 'n behoefte aan verlossing uit hierdie ontredderde gevoel gehad (Vos \& Pieterse, 1997:57; vgl. ook Van Moerkerken \& Du Rand, 1993:27). Daar is nie soseer in terme van sonde gedink nie, maar eerder in terme van geskei wees van (G)god, en 'n verlange tot hereniging met $(\mathrm{H}) \mathrm{hom}$. Die gevoel was eerder een van verlorenheid as van sondigheid (vgl. Schweizer, 1990:99).

Teen hierdie agtergrond moet die liedere wat as die Christologiese himnes bekend geword het (vgl. Barkhuizen, 1989:4), gelees word. Dit is byvoorbeeld die himnes van Johannes 1:1-18, Filppense 2:6-11, Kolossense 1:15-20 en 1 Timoteus 3:16. Die kerk van dié Kurios en Soter, Jesus Christus, het Hom in dié liedere as sodanig bely en besing. Die Bybelskrywers neem dit as deel van die formasiegebeure van die kerk in hulle geskrifte op. Christus word daarin besing en verheerlik oor wat Hy voor die skepping en tydens sy koms na die wêreld gedoen het, en oor sy uiteindelike heerskappy oor alle magte. Die verskil tussen die Christelike gemeente of kerk se himnes en dié van die Grieks-Romeinse wêreld was daarin geleë dat die Christelike lied berus het op die historiese, reddende daad van Christus (vgl. Martin, 1993c:259), die Here ook oor die kosmos. Deur die kontrastering van die kerk se NuweTestamentiese himnes met die heidense liedere word die openbaring se grondliggende belang in die ontstaan van die liturgiese lied op 'n besondere wyse beklemtoon. Die lied berus op - en die liedontstaan 
vloei voort uit - werklike, objektiewe, historiese openbaringsfeite soos die pre-eksistente Christus se lyde, opstanding en verheerliking (vgl. byvoorbeeld die himne in Filppense 2:6-11).

Gevolgtrekking: Ook uit die ontvouing van die koninkryk (soos by die deurbreek daarvan en by die interpretasie van die voleinding daarvan onderskeidelik in 2.1.2 en 2.1.3 aangetoon) vloei liedere voort, gegrond ín en as 'n gevolg ván die openbaring van God. Die Nuwe-Testamentiese liedere is dus gegrond in die openbaring van God en vloei daaruit voort.

\section{Samevattende gevolgtrekking uit 2.1.1 - 2.1.4}

Openbaring is die grond en oorsaak van liturgiese liedstof in die Nuwe Testament

\section{Basisteoretiese riglyn uit 2.1.1 - 2.1.4}

In (nuwe) liedskepping behoort die openbaring die grond en oorsaak van die liturgiese lied te wees.

2.2 Die rol van die lied in die openbaring van die Nuwe Testament

\subsubsection{Die lied aktualiseer die openbaring}

Vervolgens word gefokus op die rol van die lied in die openbaring van die Nuwe Testament (waar in die vorige punt die rol van die openbaring in die lied waargeneem is). Die lied in die Nuwe Testament is meer as 'n poëtiese vertaling en duplisering van die openbaring. Botha (1989:72) wys by die bespreking van die himne in Kolossense 1 daarop dat die betrokke himne in die dankseggingsdeel van die brief val (vers 3-23). In dié hoofstuk word dank in vers 3 tot 8 verwoord, wat in vers 9 tot 11 deur gebed gevolg word, en weer deur dank in vers 12 tot 23 afgesluit word. In die tweede dank-deel gaan die danksegging vir die verlossing van die Kolossense deur Christus (Kol. 1:12-14) direk oor in 'n lied oor Christus (Kol. 1:15-20), en dit word opgevolg deur 'n vermaning om vas te staan in hierdie verlossing (Kol. 1:21-23). Die geopenbaarde verlossing, wat 'n werklikheid is wat vasstaan, word dus verder verwerklik in die himniese geloofsrespons wat sy plek vind midde-in die dank vir die verlossing.

Gevolgtrekking: Die lied aktualiseer die openbaring. Die himne is openbaring-in-responsiewe-aksie. 


\subsubsection{Die lied konkretiseer die geaktualiseerde openbaring}

Om die rol van die lied in die openbaring vas te stel, is dit nodig om weer terug te keer na die besondere godsdienstige kultuursituasie waarin die Nuwe Testament ontstaan het. Omdat die Romeins-Griekse leefwêreld met sy gnostieke denke reeds redelik in besonderhede geskets is (2.1.4) as die agtergrond waarteen die geskrifte van die Nuwe Testament - mét hulle himniese gedeeltes - ontstaan, word hier net daarna terugverwys. Gemeenskap met 'n god wat sy volgelinge uit astrologiese magte kon bevry, was nodig. Christus is nou geopenbaar as Kurios en Soter. Hierdie openbaring word deur die Christologiese himnes (vgl. 2.1.4) geaktualiseer in die besondere omstandighede. Daarvoor gebruik die Bybelsrywers ook die liedere. Die himne sing daarom nie net van die openbaringsfeite wat "staan" nie, maar laat dit openbaring-in-aksie word. Die Beeld van die onsienlike God (Kol. 1:15) wat Here is (Fil. 2:11), word ook nou deur die liedere as sodanig verklaar. In die aktuele situasie "beweeg" die openbaring dus van die historiese, objektiewe feite wat "staan", na lewende proklamering van die openbaringsgebeure in Christus. So weerlê die lied lewendig, prakties en aktueel die dwaling, en sing dit as geloofsrespons die Christus-openbaring in in die omgewing en die leefwêreld van die jong kerk. Liedere roep dit wat dit uitsing op "om-te-wees" (vgl. Bingle, 2000:39).

Gevolgtrekking: Die geopenbaarde word in die lied meer as 'n historiese gebeurtenis waarna verwys word. Dit word deur die lied werklikheid in die konkrete situasie: Christus ís Kurios en Soter.

\section{Samevattende gevolgtrekking uit 2.2.1 en 2.2.2}

Die liedere en liedstof in die Nuwe Testament aktualiseer die openbaring in 'n konkrete konteks.

\section{Basisteoretiese riglyn uit 2.2.1 en 2.2.2}

In (nuwe) liedskepping behoort die liturgiese lied openbaring-in-responsiewe-aksie te wees wat die openbaringswaarheid konkreet aktualiseer.

\subsection{Die lied in die Nuwe Testament as artikulering van die} openbaring in belydenis van geloof (articulus fidei)

\subsubsection{Die lied en dogma}

Die lied wat sy ontstaan in die openbaring het en die openbaring aktualiseer, is wesenlik 'n geloofsbelydenis (De Klerk, 1990:58) of 'n belydenisuitspraak (Roberts, 1988:95). Dogma word in en sodoende ook deur die himne gevorm. Martin (1993a:420) stel byvoorbeeld dat die Christelike himnes in die briewe van Paulus die "nerve ends" vertoon van 
wat hy die "Pauline gospel" noem. Die liedere is soos spieëls wat die geloof van die jong kerk reflekteer (Deiss, 1979:46). In oorsprong en gebruik is himniese materiaal en belydenisse ("creedal confessions"; vgl. Wu, 1993:557) dieselfde. Dit het oorspronklik ontstaan vir evangeliserende en apologetiese doeleindes, en is ook as vermaning en lering gebruik (alles tipiese kenmerke van die belydenis van gelowiges). Viljoen maak in sy ondersoek na die sogenaamde konfessionele liedere in die Nuwe Testament (bv. 1 Tim. 1:17, 6:15-16, 2 Tim. 2:11-13) die stelling dat gelowiges mekaar ondersteun deur bymekaar te kom en hulle gemeenskaplike geloof te bely. Hieruit spruit 'n noue band tussen himnes en belydenisse (Viljoen, 1990:167).

Gevolgtrekking: Dogma word in die himne gevorm en deur die himne gedra.

\subsubsection{Die lied is belydende verheerliking}

Dit is egter nodig om daarop te let dat die himnes in die Nuwe Testament nog nie belydenisskrifte in die gewone sin van die woord is nie (dié sou later in die Christelike kerk ontwikkel), al vertoon hulle wel eienskappe van geloofsimbole wat uitkristalliseer. Die sogenaamde sakramentele liedere kan as voorbeelde genoem word van belydenis wat 'n vaste vorm begin aanneem. Efesiërs 5:14 se dooplied is moontlik die bekendste voorbeeld van 'n sakramentele lied (ander voorbeelde is moontlik Tit. 3:4-7, Rom. 6:1-11 en Ef. 2:19-22). Die himne in die Nuwe Testament vertoon myns insiens meer die aard van 'n carmen Christo ('n lied oor Christus) as 'n carmen Christi ('n lied tot Christus - vgl. vir die onderskeid: Martin, 1997:Ixxxiii), waaruit die sterk belydende aard van die himne afgelei kan word. Tog gee die liedere, ten spyte van hierdie belydende, omskrywende verwoording van geloof, nog steeds meer die indruk van 'n impressionistiese skildering van God se heilsdade in Christus (vgl. Botha, 1989:75) as wat dit die eienskappe van belydenisskrifte vertoon. Dit is dus wel liedere wat in die derde persoon oor Christus handel, maar dit impliseer nie dat hulle saaklik is nie. In Kolossense1:15-20 se lied, byvoorbeeld, gee die vroeë kerk uitdrukking aan haar belydenis van wie en wat Christus is en wat Hy alles vir haar beteken, maar dit gebeur "impressionisties, oorstelp, kunstig en byna 'at a lost of words'" (Botha, 1989:76). Kliniese logika en noukeurige kronologie van die historiese openbaringsdade staan nie voorop nie. Die belangrike wat hierin waargeneem moet word, is dat die liedere in die Nuwe Testament - soos dié in die Ou Testament - uitsprake is wat geloof artikuleer. Die himnies-poëtiese uitdrukkingswyse is dus wel articulus fidei (verwoording van geloof), maar dan in 'n vorm wat normale taalpatrone deurbreek, en nie sistematiserend van aard is of wil wees nie. Dit neem die doksa van God waar en gee erkennend uiting daaraan. 
Op God se doen en dade volg lied en lof in belydenis, maar dit is nie "sistematiese" teologie nie.

Gevolgtrekking: Geloof kristalliseer in die himne, en word daarin verwoord (articulus fidei), al word die himne nie daardeur 'n belydenisskrif nie. Dit is belydende verheerliking.

\section{Samevattende gevolgtrekking uit 2.3.1 en 2.3.2}

Dogma/geloof vind in die liedstof van die Nuwe Testament neerslag en vervul 'n verheerlikende funksie.

\section{Basisteoretiese riglyn uit 2.3.1 en 2.3.2}

In (nuwe) liedskepping behoort die belydende verheerlikingsfunksie van die lied altyd in gedagte gehou te word. Liturgiese liedere moet die openbaring artikuleer in geloof wat bely word.

\subsection{Liedinhoud in die Nuwe Testament is deur die openbaring monoteïsties bepaal}

\subsubsection{Monoteïsme in die liedere van die Nuwe Testament}

Die himniese stof van die Nuwe Testament is in die vorige perspektief ondersoek om vas te stel of en hoe dit geloof verwoord. In hierdie afdeling gaan dit nou oor die wat of die inhoud van die geloof wat in en deur die himniese stof verwoord word. By 'n oorsig oor die liedstof van die Nuwe Testament kan eerstens tot die gevolgtrekking gekom word dat die inhoud van die liedere die uitdrukking is van die ontwikkelende geloofsoortuiging van die Christelike kerk dat Jesus Christus as God naas God die Vader bely moet word (Martin, 1993c:257). In wese is dit niks anders as 'n duidelike monoteïsme wat deur die Christelike kerk bely is en liedmatig tot uitdrukking gebring is nie. Hy (Christus) is as mensgeworde Woord God se "climactic revelation" in die geskiedenis; in Hom is God se Woord en die mens se geloofsrespons vervul (Williamson, 1976:84-85). Die inhoud van die liedere trek dus ook in Hom saam. Mays (1985:63) stel dat die onderwerp van die verheerliking in die Nuwe Testament ' $n$ verrassende persoonlike konsentrasie ondergaan. Op 'n paar uitsonderings na (waarvan die verheerlikende inhoud van liedere buitendien steeds terugherlei kan word na die besondere handelinge van die één God in Christus) is die onderwerp Jesus Christus, die Seun van God. Maar hierdie verheerliking van Jesus Christus as God is nie in spanning met die monoteïsme van die Ou Testament nie. Inteendeel: dit gaan daarop terug en bou dit uit. Paulus, byvoorbeeld, bou in sy verkondiging juis op die monoteïsme van die Ou-Testamentiese belydenis van één God (vgl. die sjema van Deut. 6:4, en Jes. 45:22), maar nou is die eiesoortige belydenis van die uniekheid en enigheid van 
God gekonkretiseer in Christus. Paulus "christianize" dié belydenis met himniese belydenisse oor Christus se heerskap, sowel in sy preeksistensie (Fil. 2:6) as in sy verheerliking (Fil. 2:9-11; vgl. Martin, 1993a:192). Die geloof tydens die vroeëre openbaring het in Jahwe gesentreer en in Hom alles gehad; die geloof ná die vervulling sentreer in en het nou alles in Christus, in Wie die een God met sy volle wese woon (Kol. 1:19). Die wese van God, met ander woorde hoe God is (dus: sy deugde en attribute) is nou in Christus saamgetrek. Om Hóm (Christus) nou te bely en te verheerlik, is nie om net met verhalende lof besig te wees nie (God se selfopenbaring in Christus in Wie Hy konkreet kom handel het nie), maar ook om met beskrywende lof besig te wees (wie en hoe God is). Dit is dus steeds die één God wat verheerlik moet word. Christus is ook God, maar nie 'n ander God nie. In die Nuwe Testament in die algemeen en in die liedere daarin in die besonder is steeds 'n openbaring van monoteïsme uitgedruk, nou in 'n vorm wat die fokus van Jahwe na Christus skuif. Ten grondslag van al Paulus se gedagtes lê volgens Wright (1991:119) die volgende: “... monoteism and election, redefined by means of christology". Wright (1991:136) stel verder: "... we see the emerge of a strikingly new phenomenon: christological monoteism".

Gevolgtrekking: Die (belydenis)inhoud van die liedere in die Nuwe Testament is steeds (soos die liedere in die Ou Testament) monoteïsties bepaal, maar die monoteïsme is nou deur die openbaring in Christus 'n "herdefinisie" van die wese van die één onsienlike God.

\subsubsection{Die konsekwensie van die monoteïstiese bepaaldheid van Nuwe-Testamentiese himniese stof}

Die konsekwensie van die monoteïsme is dat die skepping (kosmos) en herskepping (verlossing) nie die handelinge van meer as een god of godheid is nie. Dit was juis kenmerkend van die godsdiensomgewing waarin die Christelike geloof sy beslag moes kry dat daar (volgens gnostieke voorstelling) geglo moes word in twee ryke, die hemelse en die aardse, waartussen bose emanasies of aeone gestrek het (vgl. hiervoor weer 2.1.4 en 2.2.2). Veelgodendom (politeïsme) is ook steeds gehandhaaf in die religieuse denke van die tyd. Teenoor dualisme en politeïsme is die verkondiging dat daar een Skepper/Verlosser is: God (vgl. Wright, 1991:118). Teenoor die gnostiese denke dat Christus deel was van 'n engele-hiërargie en nader was aan die skepping as aan die Skepper, word die himniese stof van die Nuwe Testament met die belydenisinhoud gevul dat Christus reeds in die skepping van die kosmos 'n rol gespeel het (vgl. Joh. 1:1-3, Kol. 1:15-16) en "word sy bestaan teruggevoer na God self en kon Hy as God betrokke wees by die skepping (vgl. Joh. 1:1) - nie as maaksel nie, maar as Maker" (Snyman, 1989:46). Die 
Kosmokrator en die Soter is dus nie verskillende gode nie, maar steeds die één God wat openbarend handel. Helyer (1994:235 e.v.) verwys na die kosmologiese Christologie by Paulus en noem dit selfs die kulminasie van wat Paulus oor die Persoon van Christus leer (Helyer, 1994: 241). Hierdie kulminasie is kwantitatief nie so prominent nie, maar - en dit is die merkwaardige - dit word juis in liedvorm gedra (Kol. 1:15-20). Daardeur kry dit prominensie. Skeppingsmiddelaar en Herskeppingsmiddelaar is dieselfde, en kosmosskepping en reddingsgeskiedenis staan nie teenoor mekaar as die werk van verskillende "godhede" met verskillende pligstate en funksies nie. Juis in die eenheid van God se handelinge in kosmos en verlossingsgeskiedenis is die monoteïsme Nuwe-Testamenties uitgedruk, bepaal dit die besondere belydenisinhoud van die himnes, en sing die himnes dit belydend-verheerlikend uit. Die heerlikheid van God wat nou in Christus geopenbaar is, word belydend waargeneem (dogmavorming) en verheerlikend erken (doksa-uiting).

Gevolgtrekking: Die liedere in die Nuwe Testament handhaaf kosmosskepping en reddingsgeskiedenis as 'n twee-eenheid in die werk van die één God wat Hom ook in Christus as God openbaar, en nie as gebeure binne 'n dualistiese of politeïstiese denkpatroon nie.

\section{Gevolgtrekking uit 2.4.1 en 2.4.2}

Liedere in die Nuwe Testament openbaar 'n Christologiese monoteïsme as (belydenis)inhoud - so bepaal deur die openbaring dat die kosmosskepping en die reddingsgeskiedenis 'n twee-eenheid in die werk van die één God is.

\section{Basisteoretiese riglyn uit 2.4.1 en $\mathbf{2 . 4 . 2}$}

In (nuwe) liedskepping behoort die unieke eie-aard van die Christelike geloof, naamlik Christologiese monoteïsme, uitdrukking te vind, en wel so dat die (belydenis)inhoud van die liedere deur die openbaring monoteïsties bepaal sal wees.

\subsection{Liedere in die Nuwe Testament teen 'n verbondsagtergrond}

\subsubsection{Die himniese stof van die Nuwe Testament bevat verbonds- motiewe}

Die Ou-Testamentiese verbondsagtergrond van die himniese stof in die Nuwe Testament kan duidelik aangetoon word. Dit laat die liedere in die Nuwe Testament steeds verbondsmatig funksioneer. Kyk in hierdie verband na die tipering van tussen-testamentêre liedere in hierdie artikel (2.1.2). 
- Vir byna elke motief in die Magnificat (Luk. 1:46-55) kan byvoorbeeld 'n ooreenstemmende of selfs parallelle motief in die Ou Testament gevind word. Die ooreenkoms met die verbondslied van Hanna in 1 Sameul 2:1-10 is ooglopend (vgl. Luk. 1:46 met 1 Sam. 2:1, 2; Luk. 1:51-53 met 1 Sam. 2:7-8). Vorster (1979:15-16) wys verdere ooreenkomste uit wat die lied met nog een en twintig ander Ou-Testamentgedeeltes of Joodse geskrifte uit die tydperk tussen die Ou en Nuwe Testament vertoon. Dit het met die koms van die Messias 'n vervulde verbondslied geword.

- Die verbondstaal en -motiewe is in die Benedictus (Luk. 1:68-79) nog sterker en duideliker, byvoorbeeld: "die God van Israel" wat "sy volk opsoek en verlossing bewerk" (Luk. 1:68), "die huis van sy dienaar Dawid" (Luk. 1:69), "met 'n eed bevestig aan ons voorvader Abraham" (Luk. 1:73).

- Die Nunc Dimittis (Luk. 2:29-32) is uitdrukking van die heil wat vanuit die verbondsvolk ook vir die nasies aangebreek het (Luk. 1:31-32).

Verder is verbondsmotiewe, soos 'n volk wat aan die Here behoort, in die Apokalips ook sterk teenwoordig (Op. 7:4: "uit elke stam van die volk Israel"; Op. 15:2-4: die volk van die nuwe eksodus wat die lied van Moses en die Lam sing).

Gevolgtrekking: Die lied in die Nuwe Testament ontstaan in en spruit voort uit die verbondsverhouding en -gemeenskap waarin die besonge en besingde God en die singende mens tot mekaar staan.

\subsubsection{Liedere in die Nuwe Testament adem die gemeenskaplikheid van die verbond}

Die eienskap van die verbondslied dat dit 'n gemeenskaplike lied is en nie 'n "ek-lied" nie, word in die Nuwe-Testamentiese himniese stof duidelik gesien. Juis dit maak van 'n lied 'n verbondslied dat dit nie liedere van die enkeling bly nie, maar die lied van gelowiges gesamentlik word. Die individuele sanger kry korporatiewe identiteit. Dit kan in twee van die Lukaanse himnes wat hierbo as voorbeelde aangehaal is, aangemerk word. Al is die Magnificat (Luk. 1:46-55) sterk individueel, kry die redding en verlossing in die mond van Maria meer as "Mariaanse" betekenis. Die tweede deel van die lied (Luk. 1:50-55) word 'n "paradigm for the people of God" (Bailey, 1979:29). Die Nunc Dimittis (Luk. 2:29-32) vertoon dieselfde oorgang van die individuele na die gemeenskaplike: die lied kry selfs 'n gemeenskaplikheid wat verder reik as Israel, wat uitstrek na die nasies. 
Gevolgtrekking: Die lied in die Nuwe Testament wat teen die verbondsagtergrond onstaan en verbondsmotiewe bevat, funksioneer uit die aard van die verbond as gemeenskaplike liedere.

\subsubsection{Die gemeenskaplike verbondslied is steeds persoonlik}

In Openbaring 14:3 word verwys na die honderd vier en veertig duisend se lied wat net hulle kon sing en leer. Uit die bepaling dat dit net hulle is wat van die aarde losgekoop is wat dit kon doen, blyk dat niemand wat die verlossing nie ervaar het nie, die lied kan sing nie (Viljoen, 1990:156, 159).

Gevolgtrekking: Die lied is, alhoewel gemeenskaplik, tog ook persoonlik.

\section{Gevolgtrekking uit 2.5.1 - 2.5.3}

Liedstof in die Nuwe Testament is deurgaans verbondsmatig bepaal: gemeenskaplike liedere van indiwidue wat saam binne die verbond leef.

\section{Basisteoretiese riglyn uit 2.5.1-2.5.3}

In (nuwe) liedskepping behoort die liturgiese lied 'n gemeenskaplike lied te wees waarin persoonlike verbondskommunikasie vergestalt word.

\subsection{Liedere in die Nuwe Testament en die nuwe aeon}

\subsubsection{Die liedere in die Nuwe Testament begelei die nuwe aeon}

Juis die lied is volgens Schöngen (1967:12) die mees geskikte uitdrukkingsmiddel van die nuwe aeon. So verklaar hy die belangrike funksie van die lied by die aanbreek van die vervulde koninkryk in Christus, en verwys na Petrus se aanhaling van Psalm 16 in sy Pinkstertoespraak (Hand. 2:25-28; vgl. ook 2.1.1). Dat die lied in die Nuwe Testament inderdaad die begeleier is van die nuwe ryk, was reeds duidelik by die waarneming van die rol wat die Lukaanse himnes in die koms van die nuwe ryk gespeel het (vgl. 2.1.2, 2.5.1 en 2.5.2), die liedere wat die eindtydgebeure interpreteer (vgl. 2.1.3), asook die liedere wat die formasie van die kerk tydens die ontvouing van die koninkryk begelei (vgl. onder andere 2.1.4).

Gevolgtrekking: Dit het reeds duidelik geword dat liedere in die Nuwe Testament in die koms van die nuwe aeon 'n begeleidingsfunksie het.

\subsubsection{Liedere lei in die nuwe in}

Die lied in die Nuwe Testament blyk (net soos die lied in die Ou Testament) egter nie net die begeleier van die nuwe ryk/eksodus te 
wees nie, maar ook die inleier daarin. Filippense 2:6-11 se lied kan as voorbeeld genoem word. Die kerk wat dié himne in die tyd van die Nuwe Testament gesing het, kon reeds die "Jesus Christus is Kurios" van die lied (vers 11) as 'n teenwoordige werklikheid ervaar - téén alle omstandighede wat ervaar word in. Dit is nie dat Paulus 'n verwerklikde eskatologie in sy aangehaalde himnes wil uitdruk nie. Dit is duidelik dat Hy ook die "nog nie"-faktor in die liedere inbou, soos in die himniese 1 Korintiërs 15:20-28 en die himniese uitroep Marana' ta (Aramees vir "Kom, Here!" - 1 Kor. 16:22; vgl. Martin, 1993b:988). Tog is die sangers reeds verlos van die bose, astrologiese magte (volgens die heersende voorstelling). Al was dit nog net 'n vlugtige flits van die waarheid van Christus se finale Heerskap, het dit die sangers reeds in die nuwe werklikheid ingelei. Juis dit het aan hulle die lewende versekering gegee wat hulle nodig gehad het om hulle kontemporêre wêreld/werklikheid, waarin baie "God" en "Here" genoem word (1 Kor. 8:5-6), te konfronteer (vgl. Martin, 1993c:261). Die kerk as mikro-kosmos van die heerskappy van God in Christus word deur die lied in die nuwe werklikheid ingelei. Uiteindelik sal die nuutgeskepte makro-kosmos dit ook bely (Fil. 1:11).

Gevolgtrekking: Die lied van die gelowiges lei hulle (die gelowige sangers) reeds in die nuwe werklikheid in.

\subsubsection{Die lied in die Nuwe-Testamentiese openbaring is 'n nuwe lied}

Dat die lied in die Nuwe Testament ook die funksie vervul van inleier in die nuwe wat in Christus aangebreek het, is besonder duidelik as op die term nuwe lied gelet word. Viljoen kom tot die konklusie dat "nuwe liedere" in die Apokalips (vgl. Op. 5:9, 14:3) eiesoortige liedere is wat ontstaan na aanleiding van nuwe, ingrypende dade van die Here. Dit is dade wat ' $n$ ommekeer in die geskiedenis bring en uitsig op 'n nuwe tydperk open. Om dit te besing, is 'n nuwe lied nodig (Viljoen, 1990:159). Die woord nuut (Grieks: kainos) dui in die Apokalips in onderskeiding van néos (wat tyd aandui) op kwaliteit. Die nuwe is nie soseer 'n temporele aanduiding nie, maar 'n saaklike; dit wil nie in die eerste plek sê dat dit jonger is nie, maar dat dit anders en beter is ("superior to that which is old", volgens Louw en Nida, 1988:594). Toegepas op die lied, dui die nuwe van die nuwe lied dus op die lied as inleier in die veranderde en die vervulde nuwe in Christus.

Gevolgtrekking: Die liedere in die Nuwe Testament (ver-)plaas in 'n nuwe toestand en dimensie, en nie soseer in 'n nuwe fase deur tydsverloop nie. Die nuwe lied vervul die oue, sonder om die oue te vervang. 


\section{Gevolgtrekking uit 2.6.1-2.6.3}

Liedere in die Nuwe Testament het 'n begeleidingsfunksie en 'n inleidingsfunksie ten opsigte van die nuwe aeon.

\section{Basisteoretiese riglyn uit 2.6.1-2.6.3}

In (nuwe) liedskepping behoort die liturgiese lied 'n effektiewe begeleier van die nuwe aeon te wees en "metter-lied" inlei en verplaas na die seën van die nuwe aeon.

\section{Samevatting van basisteoretiese perspektiewe op lied- materiaal in die Nuwe Testament}

- Openbaring is die grond en oorsaak van die (liturgiese) lied in die Nuwe Testament.

- Liedere en liedstof in die Nuwe Testament aktualiseer die openbaring (is openbaring-in-responsiewe-aksie).

- Liedere in die Nuwe Testament is die artikulering van die openbaring in belydenis van geloof (is articulus fidei).

- Die liedere in die nuwe Testament se (belydenis)inhoud is deur die openbaring monoteïsties bepaal.

- Die lied in die Nuwe Testament is 'n gemeenskaplike lied waarin persoonlike verbondskommunikasie vergestalt word.

- Liedere in die Nuwe Testament begelei 'n nuwe bedeling en lei ook in in die nuwe wat aanbreek.

\section{Samevattende konklusie}

Uit die ondersoek van liedstof in die Nuwe Testament kan die volgende konklusie in verband met die verhouding openbaring-dogmavormingdoksa-uiting in die (liturgiese) lied getrek word:

Die verhouding tussen openbaring, dogmavorming en doksa-uiting in die liturgiese lied is kompleks en sensitief verweef. Die openbaring staan in 'n kousale verhouding tot die dogmavorming en die doksa-uiting in die lied. Laasgenoemde twee is responsief op die openbaring, maar het ook 'n aktualiserende uitwerking op die openbaring, terwyl hulle tot mekaar in 'n konvergerende en simbiotiese verhouding in die liturgiese lied staan en sodanig daarin verbind. Die suiwer en sensitiewe verstaan van hierdie verhoudings vanuit liedere en liedmateriaal in die Nuwe Testament is baie belangrik en bepalend vir die liturgiese lied in al sy fasette. Daarsonder kan die lied se funksionaliteit as unieke liturgiese handeling in gedrang kom. Die himniese stof van die Nuwe Testament is dus 
rigtinggewend vir die vorming van liedere in 'n Nuwe-Tesamentiese aanbiddingsgemeenskap.

\section{Bibliografie}

BAILEY, J.L. \& VANDER BROEK, L.D. 1992. Literary forms of the New Testament. A handbook. Louisville : Westminster/John Knox Press.

BAILEY, K.E. 1979. The Song of Mary. Vision of a new Exodus (Luke 1:46-55). The Near East School of Theology; Theological Review, 2 (1):29-35.

BARKHUIZEN, J.H. 1989. Inleiding: Hymni Christiani. (In Barkhuizen, J.H., red. Hymni Christiani. Hervormde Teologiese Studies, Supplementum 1:1-18.)

BINGLE, J.P. 2000. Die verhouding tussen openbaring, dogmavorming en doksauiting in die liturgiese lied. Potchefstroom : PU vir CHO. (Th.M.-verhandeling.)

BOTHA, J. 1989. Die Kolossense-himne (Kol. 1:15-20). (In Barkhuizen, J.H., red. Hymni Christiani. Hervormde Teologiese Studies, Supplementum 1:54-82.)

DE KLERK, T.C. 1990. Die rol van die eredienssang in die opbou van die gemeente. Potchefstroom : PU vir CHO. (Th.M.-verhandeling.)

DEISS, L. 1979. Springtime of liturgy. O'Connell, M.J., trans. Collegeville : The Liturgical Press.

HELYER, L.L. 1994. Cosmic Christology and Col. 1:15-20. Journal of the Evangelical Theological Society (JETS), 37(2):235-246.

LOUW, J.P. 1989. Die Johannese Logos-himne (Joh. 1:1-18). (In Barkhuizen, J.H., red. Hymni Christiani. Hervormde Teologiese Studies, Supplementum 1:35-43.)

LOUW, J.P. \& NIDA, E.A. 1988. Greek-English lexicon of the New Testament based on semantic domains. Vol. 1. New York : United Bible Societies.

MARTIN, R.P. 1993a. Hymns, hymn fragments, songs, spiritual songs. (In Hawthorne, G.F., Martin, R.P., Reid, D.G., eds. Dictionary of Paul and his letters. A compendium of contemporary Biblical scholarship. Downers Grove/Leicester : InterVarsity Press. p. 419-423.)

MARTIN, R.P. 1993b. Worship. (In Hawthorne, G.F., Martin, R.P., Reid, D.G., eds. Dictionary of Paul and his letters. A compendium of contemporary Biblical scholarship. Downers Grove/Leicester : InterVarsity Press. p. 982-991.)

MARTIN, R.P. 1993c. Hymns in New Testament worship. (In Webber, R.E., ed. The complete library of Christian worship. Vol. 1. The Biblical foundations of Christian worship. Nashville : Star Song. p. 257-262.)

MARTIN, R.P. 1997. A Hymn of Christ. Philippians 2:5-11 in recent interpretation \& in the setting of early Christian worship. Downers Grove : InterVarsity Press.

MAYS, J.L. 1985. Ps. 29. Expository articles. Interpretation. A Journal of Bible and Theology, 39:60-64.

ROBERTS, J.H. 1988. Belydenisuitsprake as Pauliniese briefoorgange. Hervormde Teologiese Studies, 44(1):81-97.

SCHÖNGEN, O. 1967. Theologie der Musik. Kassel : Johannes Stauda Verlag.

SCHWEIZER, E. 1990. Colossians 1:15-20. Review and Expositor, 87:97-104.

SNYMAN, A.H. 1989. Die Filippense-himne. (In Barkhuizen, J.H., red. Hymni Christiani. Hervormde Teologiese Studies, Supplementum 1:44-53.)

STRYDOM, W.M.L. 1984. Die aard van Himnologie en die plek daarvan in die Liturgiek. Bloemfontein : Dept. Diakoniologie, UOVS. (M.Th.-verhandeling.)

VAN MOERKERKEN, E.G. \& DU RAND, J.A. 1993. Die besondere plek en betekenis van die liedere in Openbaring 4:1-8:5 in die narratief van Openbaring. Ned. Geref. Teologiese Tydskrif, 34(1):27-34. 
VILJOEN, F.P. 1990. Die betekenis van "Psalmois, Humnois" en "Odais Pneumatikais" in Kolossense 3:16 en Efesiërs 5:19. Potchefstroom : PU vir CHO. (Th.D.- proefskrif.)

VORSTER, W.S. 1979. 'n Loflied van 'n arm vrou - die Magnificat (Lukas 1:46-55). (In Loader, J.A., red. 'n Nuwe lied vir die Here. Pretoria/Kaapstad : HAUM. p. 13-28.)

VORSTER, W.S. 1989. Die Lukaanse liedere. (In Barkhuizen, J.H., red. Hymni Christiani. Hervormde Teologiese Studies. Supplementum 1:19-34.)

VOS, C.J.A. \& PIETERSE, H.J.C. 1997. Hoe lieflik is u woning. Studies in Praktiese Teologie. Pretoria : Raad vir Geesteswetenskaplike Navorsing.

WILLIAMSON, F. 1976 [1967]. The Lord's Song and the ministry of the church. Michigan/High Wycombe : University Microfilms International.

WRIGHT, N.T. 1991. The climax of the covenant. Christ and the law in Pauline theology. Edinburgh : Clark.

WU, J.L. 1993. Liturgical elements. (In Hawthorne, G.F., Martin, R.P., eds. Dictionary of Paul and his letters. A compendium of contemporary Biblical scholarship. Downers Grove/Leichester : InterVarsity Press. p. 557-560.)

\section{Kernbegrippe:}

dogmavorming

doksa-uiting

belydenis

himniese stof

openbaring

Key concepts:

confession

dogma; the forming of

doxa; the expression of

doxology

hymnal matter

revelation 